Document downloaded from:

http://hdl.handle.net/10251/149087

This paper must be cited as:

Cembrero-Coca, P.; Cembrero Cil, J.; Busquets Mataix, DJ.; Pérez Puig, MA.; Marí, B.; Pruna, Al. (2017). Factorial electrochemical design for tailoring of morphological and optical properties of Cu2O. Materials Science and Technology. 33(17):2102-2109. https://doi.org/10.1080/02670836.2017.1349595

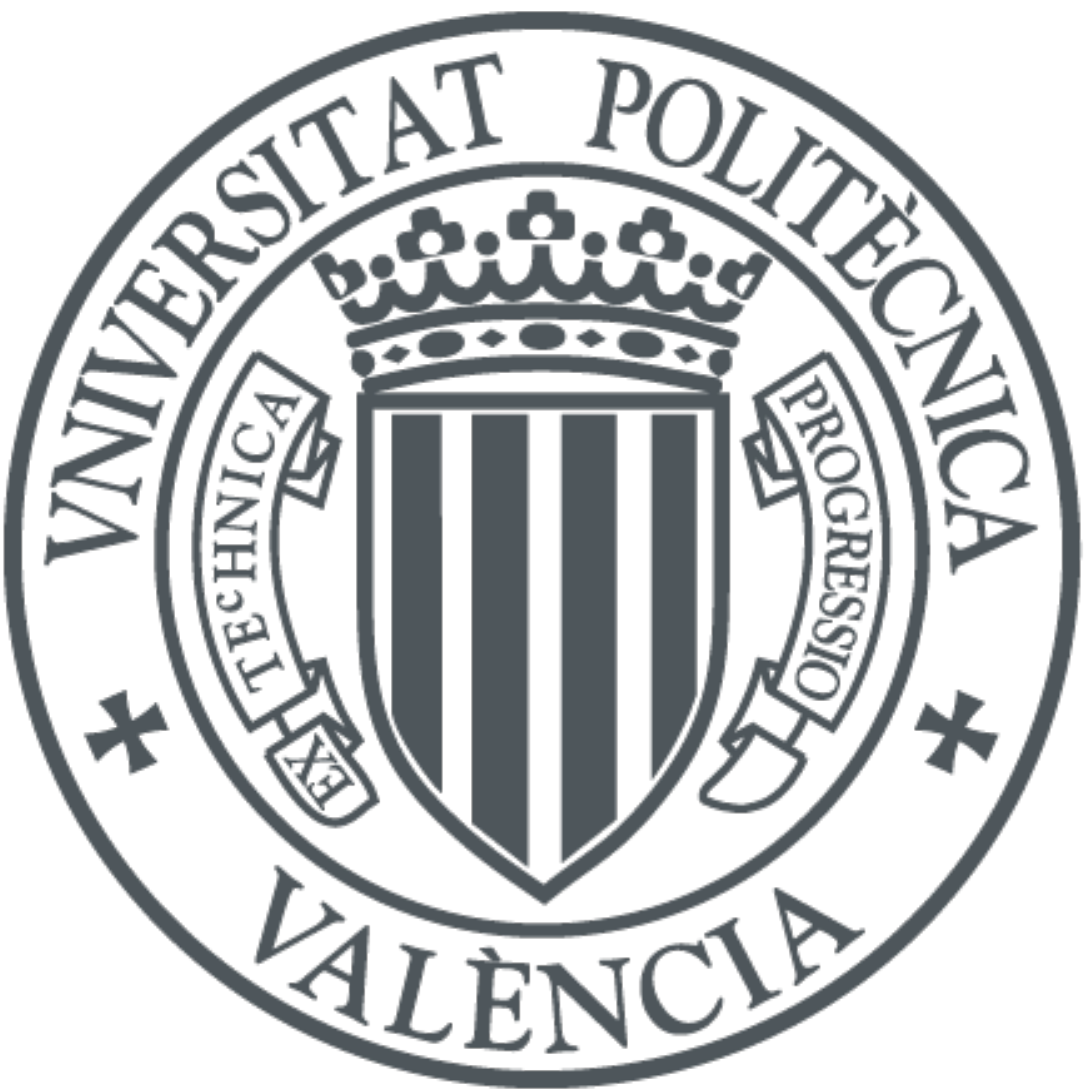

The final publication is available at

https://doi.org/10.1080/02670836.2017.1349595

Copyright Maney Publishing

Additional Information 


\title{
Factorial electrochemical design for tailoring of morphological and optical properties of $\mathrm{Cu}_{2} \mathrm{O}$
}

\author{
Paula Cembrero-Coca ${ }^{\mathrm{a}}$, Jesús Cembrero ${ }^{\mathrm{b}}$, David Busquets-Mataix ${ }^{\mathrm{b}}$, Miguel Angel Pérez-Puig ${ }^{\mathrm{b}}$, \\ Bernabé María \& Alina Pruna ${ }^{\mathrm{c}}$ \\ a Department of Applied Physics, Universitat Politecnica de Valencia, Valencia, Spain; \\ ${ }^{b}$ Department of Materials and Mechanical Engineering, Universitat Politecnica de Valencia, Valencia, Spain; \\ c Center for Surface Science and Nanotechnology, University Politehnica of Bucharest, Bucharest, Romania
}

\begin{abstract}
The electrodeposition of cuprous oxide $\left(\mathrm{Cu}_{2} \mathrm{O}\right)$ onto FTO-coated glass substrate was studied by using a statistical approach in order to control the Cu2O morphology and optical properties. The factorial design considered four electrodeposition conditions at two representative levels as input variables (electrolyte temperature and $\mathrm{pH}$, deposition potential and duration) and the deposition charge and morphology of obtained Cu2O as the output variables. The morphology analysis showed the highest influence on crystal shape was exhibited by electrolyte temperature and $\mathrm{pH}$, reaching significance levels of 95 and $98 \%$, respectively. Temperature as low as $35^{\circ} \mathrm{C}$ and $\mathrm{pH} 12.2$ results in cubic morphology, while other parameters result in octahedron shape. The highest absorbance was exhibited by the $\mathrm{Cu}_{2} \mathrm{O}$ with cubic morphology.
\end{abstract}

Key Words: Electrodeposition, morphologies of $\mathrm{Cu}_{2} \mathrm{O}$, 2-level factorial design.

\section{1.- INTRODUCTION}

Cuprous oxide, $\mathrm{Cu}_{2} \mathrm{O}$, also known as mineral cuprite, is a transition metal oxide, reddish grey in colour, with a density of 6 gr.cm ${ }^{-3}$, that crystallizes in a face centered cubic lattice (fcc) with a lattice parameter of $4,267 \cdot 10^{-10} \mathrm{~m}[1]$.

This mineral occurs naturally, generally in the form of octahedral crystals, although cubic and dodecahedral crystals are by no means rare. On occasions it can also be found in the form of bright red fibrous crystals.

Due to its being a p-type semiconductor, it is used in thin layers for optical and optoelectronic applications. These applications are particularly based on the direct energy gap $(2.0 \mathrm{eV}$ a $300 \mathrm{~K})$, have a high absorption coefficient in the visible region and an estimated theoretical solar conversion efficiency of approximately $12 \%[2,3,4]$. 
Cuprous oxide of different morphologies (thin layers, cubes, octahedral, fibers, etc.) can be grown by a number of different deposition techniques, such as chemical vapor deposition (CVD), spray pyrolysis, thermal oxidation, sputtering, chemical oxidation and electrodeposition.

The techniques used to obtain semiconductors have evolved from the primitive fused salt electrolysis, used particularly in $\mathrm{Si}$ and Ge purification, up to the methods in current use, as mentioned above, of which electrodeposition is the most widely used.

Since most of these techniques produce films with a mix of $\mathrm{Cu}_{2} \mathrm{O}$ and $\mathrm{CuO}$, it is highly important to find the specific synthesis reaction parameters of pure $\mathrm{Cu}_{2} \mathrm{O}$.

In the present study we used the cathodic reduction method by applying electrodeposition (ELD) $[5,6,7]$ to a glass substrate coated with a conductive layer of fluorine doped tin oxide (FTO). In previous studies we had experimentally determined the optimal parameters of temperature, potential, $\mathrm{pH}$ and electrodeposition time for film growth. Optical property spectra were also carried out at ambient temperature to study the evolution of optical emission properties of the different morphologies obtained.

\section{EXPERIMENTAL PROCEDURE AND RESULTS}

\subsection{Experimental Procedure}

Samples were obtained by electrodeposition (ELD) on a $1 \times 3 \mathrm{~cm}^{2}$ glass substrate coated with a thin layer of fluorine doped tin oxide (FTO).

For the control of applied potential, exposure time and temperature, a Model 263A potentiostatgalvanostat and its corresponding cell (EG\&G DIVISION INSTRUMENTS, INC.) was used. The electrolyte was heated by a water bath.

The reference electrode used was $\mathrm{Ag} / \mathrm{AgCl}$ in a saturated solution of $\mathrm{KCl} / \mathrm{AgCl}$ and a $\mathrm{Pt}$ counterelectrode. Electrolyte was a solution of: $\mathrm{SO}_{4} \mathrm{Cu}(0,4 \mathrm{M})+$ Lactic Ac. $(3 \mathrm{M})+\mathrm{Na} \mathrm{OH}(4 \mathrm{M})+$ de-ionized water.

Previous to electrodeposition, potentiostatic voltammetry of $+1 \mathrm{a}-1$ volts was performed to determine the range in which reduction processes would occur. 


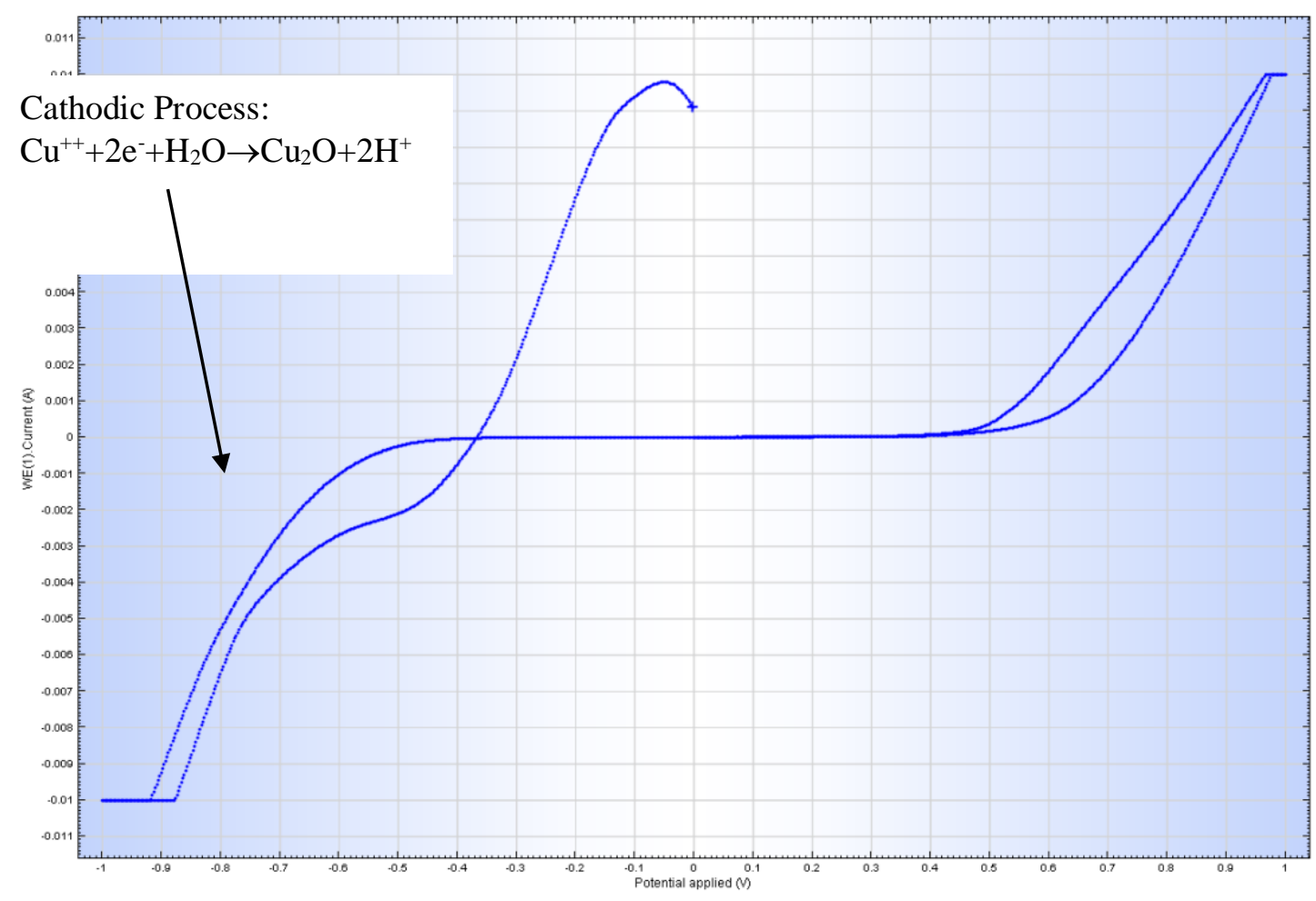

Figure 1.- Potentiostatic voltammetry

As can be seen in Figure 1, reduction processes took place within a potential range of $-0.5 \mathrm{~V}$ to -0.9 $\mathrm{V}$, at $35^{\circ} \mathrm{C}$ and $60^{\circ} \mathrm{C}$ with no apparent differences between these temperatures.

From a study of the Pourbaix diagram [8] of a $\mathrm{Cu}-\mathrm{H}_{2} \mathrm{O}$ system with lactic acid at $25{ }^{\circ} \mathrm{C}$, it can be seen that the $\mathrm{Cu}^{++}$stability area increases when lactic acid is added to the solution, thus raising the $\mathrm{pH}$ range, so that it is possible to have $\mathrm{Cu}^{++}$without precipitating $\mathrm{CuO}$. In other words, lactic acid is added to the solution as a complexing agent on $\mathrm{Cu}^{++}$until it is reduced to $\mathrm{Cu}_{2} \mathrm{O}$.

Morphological characterization of the deposited structures was by Field Emission SEM. As can be seen in Figure 2, the predominant morphologies were cubes and octahedrons. 


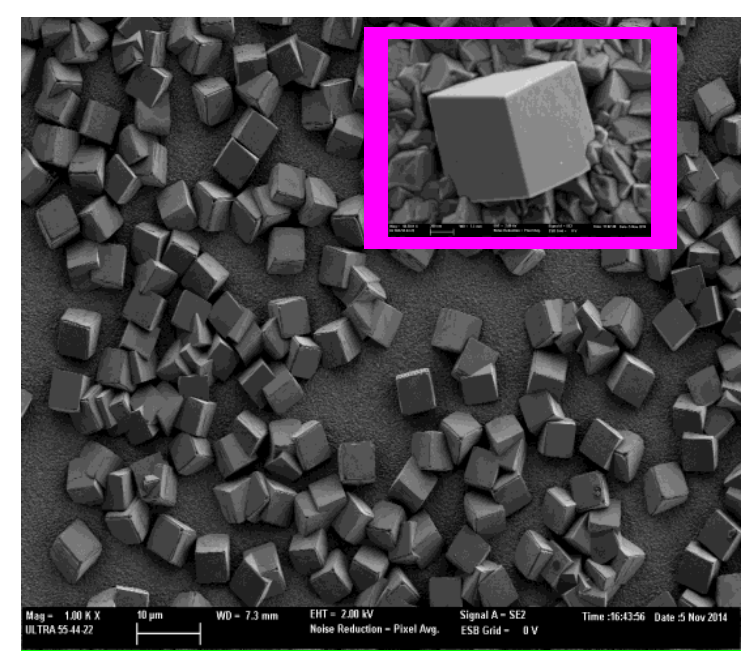

a)

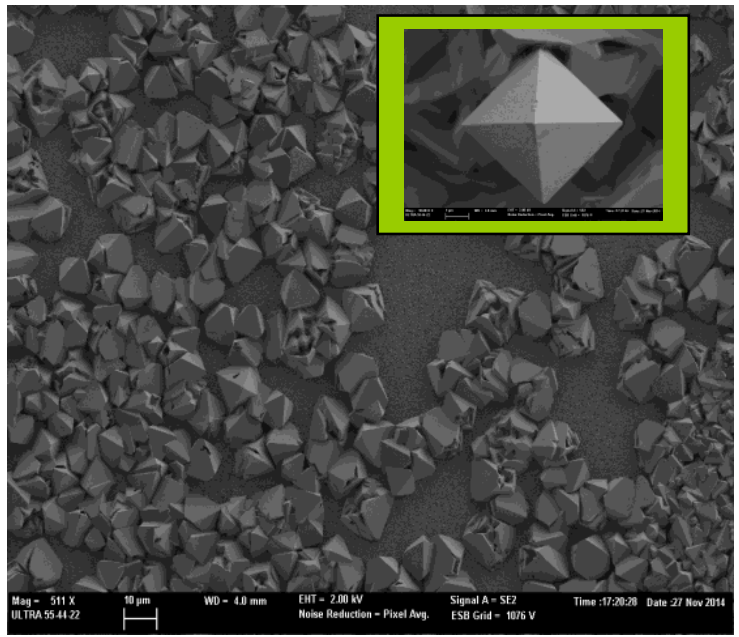

b)

Figure 2. Characteristic morphologies of $\mathrm{Cu}_{2} \mathrm{O}$ : a) Cubes; b) Octahedrals.

The crystalline structure and coating were studied by X-ray diffraction (Rigaku ULTIMA IV diffractometer), with $\mathrm{CuK}$ radiation and $0.5^{\circ}$ angle of incidence.

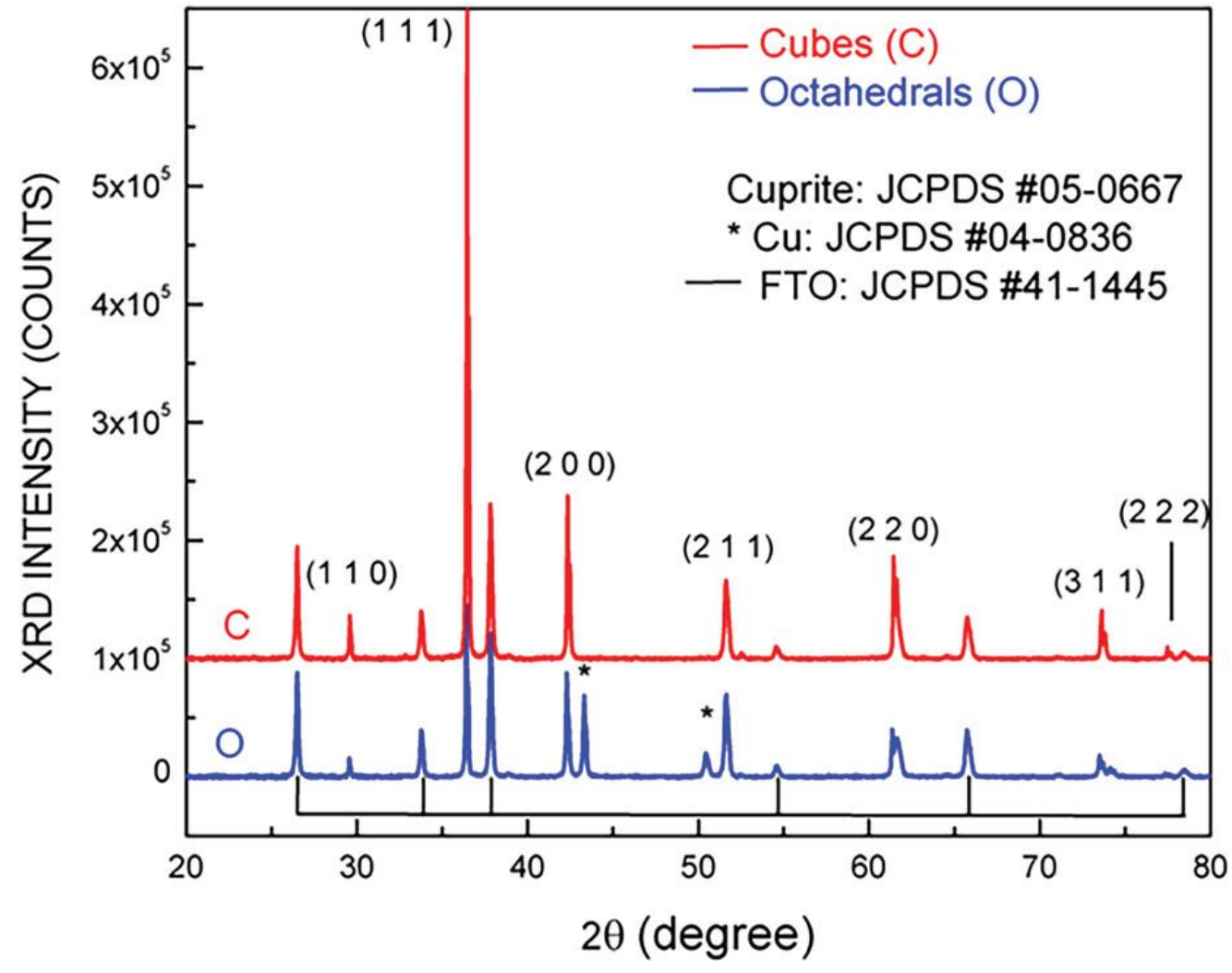

Figure 3. Diffractogram of $\mathrm{Cu}_{2} \mathrm{O}$ deposited on FTO.

Figure 3 and Table 1 show the diffractogram of the $\mathrm{m} 3$ sample and the corresponding $2 \theta$ diffraction angles of $\mathrm{Cu}_{2} \mathrm{O}$ and $\mathrm{FTO}$. 


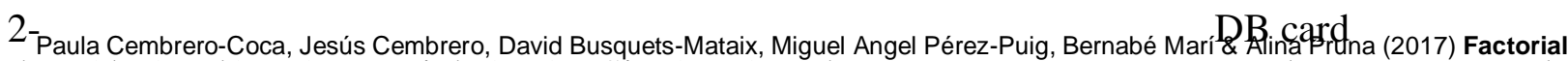

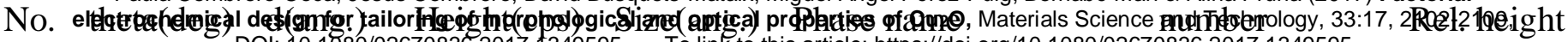

$\begin{array}{rrrrrlll}1 & 26.4999 & 3.36075 & 56404.28 & 557.83 & \text { Cassiterite, } \operatorname{syn}(1,1,0) & 008-041-1445 & 14.68 \\ 2 & 29.5818 & 3.01725 & 22073.54 & 1029.88 & \text { Cuprite, } \operatorname{syn}(1,1,0) & 00-005-0667 & 5.74 \\ 3 & 33.7765 & 2.65152 & 24330.51 & 537.54 & \text { Cassiterite, } \operatorname{syn}(1,0,1) & 00-041-1445 & 6.33 \\ 4 & 36.4415 & 2.46349 & 384298.34 & 928.57 & \text { Cuprite, } \operatorname{syn}(1,1,1) & 00-005-0667 & 100 \\ 5 & 37.825 & 2.3761 & 75953.74 & 534.11 & \text { Cassiterite, } \operatorname{syn}(2,0,0) & 00-041-1445 & 19.76 \\ 6 & 42.3234 & 2.13374 & 79274.29 & 910.33 & \text { Cuprite, } \operatorname{syn}(2,0,0) & 00-005-0667 & 20.63 \\ 7 & 51.6221 & 1.76912 & 43811.36 & 419.37 & \text { Cassiterite, } \operatorname{syn}(2,1,1) & 00-041-1445 & 11.4 \\ 8 & 52.4883 & 1.74194 & 3607.02 & 925.98 & \text { Cuprite, } \operatorname{syn}(2,1,1) & 00-005-0667 & 0.94 \\ 9 & 54.5841 & 1.67991 & 5979.12 & 351 & \text { Cassiterite, } \operatorname{syn}(2,2,0) & 00-041-1445 & 1.56 \\ 10 & 61.3915 & 1.50894 & 50673.93 & 818 & \text { Cuprite, } \operatorname{syn}(2,2,0) & 00-005-0667 & 13.19 \\ 11 & 61.671 & 1.50277 & 21427.62 & 383.74 & \text { Cassiterite, } \operatorname{syn}(3,1,0) & 00-041-1445 & 5.58 \\ 12 & 64.4371 & 1.44477 & 449.49 & 333.57 & \text { Cassiterite, } \operatorname{syn}(1,1,2) & 00-041-1445 & 0.12 \\ 13 & 65.7262 & 1.41952 & 24502.53 & 393.61 & \text { Cassiterite, } \operatorname{syn}(3,0,1) & 00-041-1445 & 6.38 \\ 14 & 73.5411 & 1.28678 & 27932.36 & 795.46 & \text { Cuprite, } \operatorname{syn}(3,1,1) & 00-005-0667 & 7.27 \\ 15 & 77.4036 & 1.23192 & 6658.03 & 677.97 & \text { Cuprite, } \operatorname{syn}(2,2,2) & 00-005-0667 & 1.73 \\ 16 & 78.4603 & 1.21796 & 3454.16 & 305.81 & \text { Cassiterite, } \operatorname{syn}(3,2,1) & 00-041-1445 & 0.9\end{array}$

Table 1. Values of $2 \theta$ diffraction angles of $\mathrm{Cu}_{2} \mathrm{O}$ and FTO.

To keep the number of experiments (prepared samples) to a minimum, a 2-level factorial design was adopted [9].

As there were four variables or factors to be considered at two levels, this approach involved 16 experiments $\left(2 \times 2 \times 2 \times 2=2^{4}\right)$.

Table 2 gives the values of the parameters in each experiment.

Table 2.Variables or control parameters and work levels.

\begin{tabular}{|c|c|c|c|}
\hline Variable or factor & Codified Var. & Low level (-) & High level $(+)$ \\
\hline Temperature & $\mathrm{A}$ & $35^{\circ} \mathrm{C}$ & $60^{\circ} \mathrm{C}$ \\
\hline Potential & $\mathrm{B}$ & $-700 \mathrm{mV}$ & $-500 \mathrm{mV}$ \\
\hline ph & $\mathrm{C}$ & 12.18 & 12.8 \\
\hline Time & $\mathrm{D}$ & 35 minutes & 75 minutes \\
\hline
\end{tabular}

Table 3. Design matrix, deposited charge aand morphologies (cubes and octahedrons)

\begin{tabular}{|c|c|c|c|c|c|c|c|}
\hline Sample & $\mathbf{A}$ & $\mathbf{B}$ & $\mathbf{C}$ & $\mathbf{D}$ & $\begin{array}{c}\text { \% cubes } \\
\text { and/or } \\
\text { octahedrons }\end{array}$ & $\begin{array}{c}\text { Deposited } \\
\text { charge }\end{array}$ & $\begin{array}{c}\text { Deposited } \\
\text { charge } \\
\text { C/cm }\end{array}$ \\
\hline $\mathrm{m} 1$ & - & - & - & - & $80 \%$ cubes & 4.684 & 1.87 \\
\hline $\mathrm{m} 2$ & + & - & - & - & $100 \%$ octas. & 6.64 & 2.66 \\
\hline $\mathrm{m} 3$ & - & + & - & - & All cubes & 2.43 & 0.97 \\
\hline $\mathrm{m} 4$ & + & + & - & - & 100 octas. & 5.40 & 2.16 \\
\hline $\mathrm{m} 5$ & - & - & + & - & 100 octas. & 2.12 & 0.85 \\
\hline $\mathrm{m} 6$ & + & - & + & - & 100 octas. & 3.63 & 1.45 \\
\hline $\mathrm{m} 7$ & - & + & + & - & 100 octas. & 0.038 & 0.015 \\
\hline $\mathrm{m} 8$ & + & + & + & - & 70 octas. & 0.70 & 0.28 \\
\hline $\mathrm{m} 9$ & - & - & - & + & $100 \%$ Cubes & 10.55 & 4.22 \\
\hline $\mathrm{m} 10$ & + & - & - & + & 50 Cubes 50 & 8,317 & 3.32 \\
\hline
\end{tabular}




\begin{tabular}{|c|c|c|c|c|c|c|c|}
\hline & & & & & 0ctas. & & \\
\hline $\mathrm{m} 11$ & - & + & - & + & $95 \%$ cubes & 5.32 & 2.13 \\
\hline $\mathrm{m} 12$ & + & + & - & + & $100 \%$ octas. & 12.76 & 5.10 \\
\hline $\mathrm{m} 13$ & - & - & + & + & $100 \%$ octas. & 1.70 & 0.68 \\
\hline $\mathrm{m} 14$ & + & - & + & + & $100 \%$ octas. & 3.57 & 1.48 \\
\hline $\mathrm{m} 15$ & - & + & + & + & $90 \%$ octas. & 0.17 & 0.068 \\
\hline $\mathrm{m} 16$ & + & + & + & + & $100 \%$ octas. & 0.583 & 0.2332 \\
\hline
\end{tabular}

Table 3 gives the results obtained (deposited charge and morphology) by combining the two levels of the factors considered, as shown in Table 2:

Optical properties (transmittance) were determined by a spectrophotometer with integrating sphere and CCD detector optimized for the UV-VIS range. The spectra obtained are shown in Figure 4.
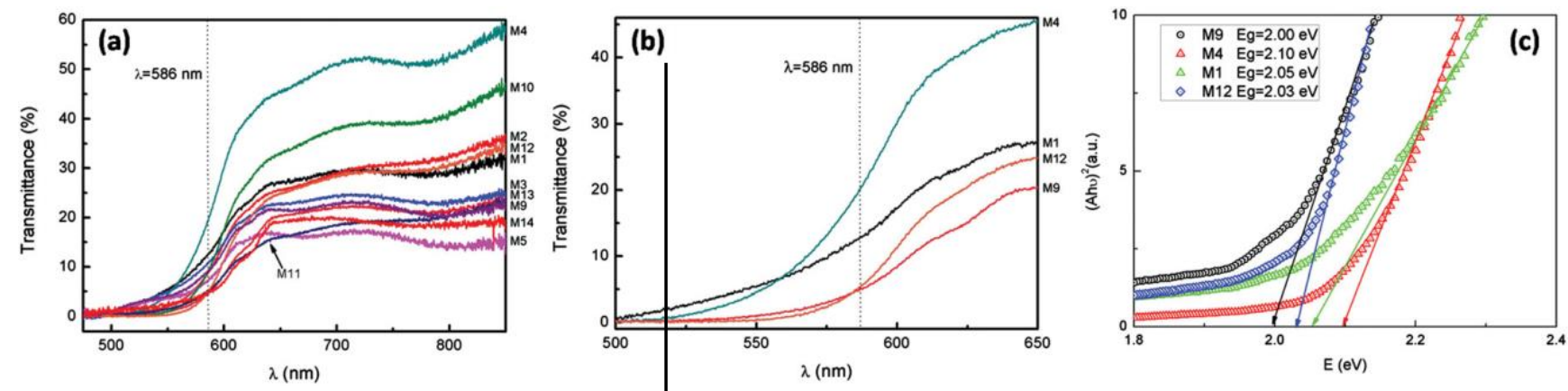

Figure 4. Optical transmis $\$$ ion spectra of samples ( $\mathrm{m}_{1}$ to $\left.\mathrm{m}_{16}\right)$ of $\mathrm{Cu}_{2} \mathrm{O}$.

\subsection{Analysis of results}

In this study we analyzed designs in which each variable or factor occurred only at two levels, identified as lower (-) and higher (+). General factorial designs and 2-level designs are important since few experiments are required for each factor, and, in spite of not being able to exhaustively explore a large region of the factor space, they can point to tendencies and so indicate a promising line for future studies. An additional advantage is that the results can be interpreted to a large extent by means of common sense and simple arithmetic.

The response variables, deposited charge and morphology were analyzed by a standard Yates algorithm on STRATGRAPHICS software [10].

\subsection{Interpretation of results}

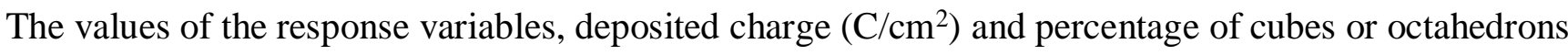
were analyzed by a Yates algorithm, for which the experiments were placed in the standard order, as seen in Table 3 (STATGRAPHICS Plus. Version 5.0 software was used).

For the deposited charge response variable, the analysis is: 


$$
\begin{array}{ll}
\text { Average } & =1.71789+/-0.202731 \\
\text { A:Factor_A } & =0.735025+/-0.405462 \\
\text { B:Factor_B } & =-0.696725+/-0.405462 \\
\text { C:Factor_C } & =-2.17172+/-0.405462 \\
\text { D:Factor_D } & =0.872025+/-0.405462 \\
\text { AB } & =0.412525+/-0.405462 \\
\text { AC } \quad=-0.277475+/-0.405462 \\
\text { AD } \quad=0.023775+/-0.405462 \\
\text { BC } \quad=-0.269225+/-0.405462 \\
\text { BD } \quad=0.154525+/-0.405462 \\
\text { CD } \quad=-0.905475+/-0.405462
\end{array}
$$

The effect of a factor is understood to be a change in the response of the factor from level (-) to (+).

There is an interaction between two factors if the effect of one of them is modified on changing the considered levels of another factor.

The interpretation of the process development data indicates that the mean value of deposited charge is $1.71789\left(\mathrm{C} / \mathrm{cm}^{2}\right)$ for the 16 cases studied.

The effects of some factors and interactions of two factors are also seen to be significant.

Thus, factor A (process temperature) causes the response variable (deposited charge) to rise by 0.735025 on moving from low level $35^{\circ} \mathrm{C}(-)$ to high level $60^{\circ} \mathrm{C}(+)$ in the process for all conditions of other factors.

Similarly, factor $\mathrm{C}(\mathrm{pH})$ is the most significant and lowers the response variable by 2.17172 units on changing from $12.18(-)$ to $12.80(+)$.

A more powerful analysis can be carried out with Analysis of Variance (ANOVA) (Table 4), which studies the effect of one or more factors on the mean of the response variable. We used STATGRAPHICS Plus Version 5.0 for these calculations.

Table 4. Analysis of Variance

\begin{tabular}{lccccc}
\hline Source & Sum of Squares & Gl & $\begin{array}{c}\text { Mean } \\
\text { square }\end{array}$ & F-Ratio & P-Value \\
\hline A: Factor A & 2.16105 & 1 & 2.16105 & 3.29 & 0.1296 \\
B: Factor B & 1.9417 & 1 & 1.9417 & 2.95 & 0.1464 \\
C: Factor C & 18.8656 & 1 & 18.8656 & 28.69 & $\mathbf{0 . 0 0 3 0}$
\end{tabular}




\begin{tabular}{lccccc} 
D: Factor D & 3.04171 & 1 & 3.04171 & 4.63 & $\mathbf{0 . 0 8 4 2}$ \\
$\mathrm{AB}$ & 0.680708 & 1 & 0.680708 & 1.04 & 0.3556 \\
$\mathrm{AC}$ & 0.30797 & 1 & 0.30797 & 0.47 & 0.5242 \\
$\mathrm{AD}$ & 0.002261 & 1 & 0.002261 & 0.00 & 0.9555 \\
$\mathrm{BC}$ & 0.289928 & 1 & 0.289928 & 0.44 & 0.5361 \\
$\mathrm{BD}$ & 0.0955119 & 1 & 0.0955119 & 0.15 & 0.7188 \\
$\mathrm{CD}$ & 3.27954 & 1 & 3.27954 & 4.99 & $\mathbf{0 . 0 7 5 9}$ \\
Total error & 3.288 & 5 & 0.657599 & & \\
\hline Total (corr.) & & 15 & & & \\
Total (corr.) & 33.9539 & 15 & &
\end{tabular}

The interpretation of the results indicates that the $\mathrm{pH}$ factor (coded $\mathrm{C}$ ) is significant to a level of $99.7 \%$, time (coded D) to $91,6 \%$ and the $\mathrm{CD}$ interaction to $92.41 \%$, i.e. they influence the response variable by either raising or lowering it by the calculated value (Table II). The other factors and interactions are not significant at this level.

For the deposited morphology response variable (cube formation) the analysis is:

$$
\begin{aligned}
& \text { Mean }=29.0625+/-3.98483 \\
& \text { A:Factor_A }=-38.125+/-7.96967 \\
& \text { B:Factor_B }=0.625+/-7.96967 \\
& \text { C:Factor_C }=-48.125+/-7.96967 \\
& \text { D:Factor_D }=5.625+/-7.96967 \\
& \mathrm{AB}=-5.625+/-7.96967 \\
& \mathrm{AC}=43.125+/-7.96967 \\
& \mathrm{AD}=-0.625+/-7.96967 \\
& \mathrm{BC}=9.375+/-7.96967 \\
& \mathrm{BD}=-11.875+/-7.96967 \\
& \mathrm{CD}=-10.625+/-7.96967
\end{aligned}
$$

The interpretation of the process development data indicates that the mean value of cube formation is 29.0625 for the 16 cases studied. The most significant factors are: temperature (factor A), $\mathrm{pH}$ (factor $\mathrm{C}$ ), and $\mathrm{AC}$ interaction (factors $\mathrm{A}$ and $\mathrm{C}$ considered jointly). This information is confirmed by the variance analysis in Table 5.

Table 5. Analysis of Variance

\begin{tabular}{lccccc}
\hline Source & Sum of Squares & Gl & $\begin{array}{c}\text { Mean } \\
\text { square }\end{array}$ & F-Ratio & P-Value \\
\hline A: Factor A & 5814.06 & 1 & 5814.06 & 22.88 & $\mathbf{0 . 0 0 5 0}$ \\
B: Factor B & 1.5625 & 1 & 1.5625 & 0.01 & 0.9405 \\
C: Factor C & 9264.06 & 1 & 9264.06 & 36.46 & $\mathbf{0 . 0 0 1 8}$ \\
D: Factor D & 126.563 & & 126.563 & 0.50 & 0.5118 \\
AB & 126.563 & & 126.563 & 0.50 & 0.5118
\end{tabular}




\begin{tabular}{|c|c|c|c|c|c|}
\hline $\mathrm{AC}$ & 7439.06 & 1 & 7439.06 & 29.28 & 0.0029 \\
\hline $\mathrm{AD}$ & 1.5625 & 1 & 1.5625 & 0.01 & 0.9405 \\
\hline $\mathrm{BC}$ & 351.563 & 1 & 351.563 & 1.38 & 0.2924 \\
\hline $\mathrm{BD}$ & 564.063 & 1 & 564.063 & 2.22 & 0.1964 \\
\hline $\mathrm{CD}$ & 451.563 & & 451.563 & 1.78 & 0.2400 \\
\hline Total error & 1270.31 & 5 & 254.063 & & \\
\hline Total (corr.) & & 15 & & & \\
\hline
\end{tabular}

This analysis confirms that temperature (factor $\mathrm{A}$ ) is significant to $99.5 \%$ ( $\mathrm{P}$-value 0.005 ), $\mathrm{pH}$ (factor C) to $99.99 \%$ (P-value 0.0018 ) and $\mathrm{AC}$ interaction also to $99.99 \%$.

Also, according to Figure 4, considering that the $\mathrm{Cu}_{2} \mathrm{O}$ bandgap $(2 \mathrm{eV})$ limits usable wavelengths $\leq$ $586 \mathrm{~nm}$, it can be seen that the highest absorbances are found in samples $\mathrm{m}_{1}, \mathrm{~m}_{2}, \mathrm{~m}_{3}, \mathrm{~m}_{4}, \mathrm{~m}_{5}, \mathrm{~m}_{9}, \mathrm{~m}_{10}$, $\mathrm{m}_{11}, \mathrm{~m}_{12}$ and $\mathrm{m}_{13}$. It can also be seen that for equal deposited charges the samples with cubic morphology have greater absorption than those with octahedral morphology (e.g. $m_{3}$ and $m_{5}$ or $m_{1}$ and $\mathrm{m}_{6}$ ). This is undoubtedly due to the External Surface/Volume ratio of the cubic samples being greater than that of the octahedral samples. As can be seen in Figure 2 and for the observed parameter of the edge of cube $=1.333 \cdot 10^{-6} \mathrm{~m}$ compared to $=5.1 \cdot 10^{-6} \mathrm{~m}$, the $\mathrm{S} / \mathrm{V}$ ratio of the cube is 3.2 times greater than that of the octahedron.

\section{Conclusions}

The factorial design of $\mathrm{Cu} 2 \mathrm{O}$ electrodeposition indicated the deposition charge can be controlled by electrolyte $\mathrm{pH}$ (significance 99.7\%) and deposition duration (significance 91.6\%). For specific shaped $\mathrm{Cu} 2 \mathrm{O}$ crystals, electrolyte temperature and $\mathrm{pH}$ showed the most significant effects, reaching levels of 95 and $98 \%$, respectively (when temperature increased from 35 to $60{ }^{\circ} \mathrm{C}$ and $\mathrm{pH}$ from 12.2 to 12.8 ), that is predominant cubicmorphology can be obtained at $35 \AA a ̃ \mathrm{C}$ and $\mathrm{pH} 12.2$. The $\mathrm{Cu} 2 \mathrm{O}$ films with predominantly cubic morphology exhibited the lowest transmittance. This work highlights the importance of combined electrodeposition conditions in order to tailor both morphological and optical properties of $\mathrm{Cu} 2 \mathrm{O}$ films for optoelectronic applications.

\section{Acknowledgements}

The authors thank for the support from Electron Microscopy Service, Polytechnic University of Valencia. 
Paula Cembrero-Coca, Jesús Cembrero, David Busquets-Mataix, Miguel Angel Pérez-Puig, Bernabé Marí \& Alina Pruna (2017) Factorial electrochemical design for tailoring of morphological and optical properties of Cu2O, Materials Science and Technology, 33:17, 2102-2109, DOI: 10.1080/02670836.2017.1349595 To link to this article: https://doi.org/10.1080/02670836.2017.1349595

\section{References}

[1] R.W.G. Wyckoff, “Crystal Structures”, Vol 1, Ed. Wiley, New York (1965).

[2] A.E. Rakhshani, Solid State Electron. 29 (1986) 7.

[3] Chen, L.C., Review of preparation and optoelectronic of $\mathrm{Cu} 2 \mathrm{O}$ - based solar cells with nanostructure. Materials Science in Semiconductor Processing, 16 (2013), p. 1172

[4] Hsu, Y.K., Lin, H.H., Wu, J.R., Chen, M.H., Chen, Y.C., and Lin, Y.G., Electrochemical growth and characterization of a $\mathrm{p}-\mathrm{Cu} 2 \mathrm{O}$ thin film on $\mathrm{ZnO}$ nanorods for solar cell application. RSC Advances, (2014) 4 (15) p 7655-7659

[5] J.O.M. Bockris, A.K.M. Reddy, Modern Electrochemistry, Plenum Press, 1998. [13] J.

[6] E. Budevski, G. Staikov and W.J. Lorenz, Electrochim. Acta, 45 (2000) 2559.

[7] D.M. Kold, in: H. Gerischer, C.W. Tobias (Eds), in: “Advance Electrochem. Eng.” Vol 11, Wiley, New York (1978).

[8] Marcel Pourbaix, "Atlas of Electrochemical Equilibria IV y V" Ed. National Association of corrosion Engineers, Houston, Texas (1974)

[9] G.E.P. Box, W.G. Hunter, J.S. Hunter «Statistics for Experimenters. An Introduction to Design, Data Analysis, and Model Building », pp 317-362 en Editorial Reverté, S.A. Barcelona (España) 1999.

[10] Pérez, C. "Estadística Práctica con Statgraphics" Cap 17. Pearson Educación, S.A. Barcelona (España) 2001. 